Crop Breeding and Applied Biotechnology 14: 180-186, 2014

Brazilian Society of Plant Breeding. Printed in Brazil

\title{
ARTICLE
}

http://dx.doi.org/10.1590/1984-70332014 v14n3a27

\section{Marker-assisted selection strategies for developing resistant soybean plants to cyst nematode}

Fernanda Abreu Santana ${ }^{1 *}$, Martha Freire da Silva ${ }^{2}$, Julierme Kellen Freitas Guimarães $^{2}$, Marcia Flores da Silva Ferreira ${ }^{3}$, Waldir Dias Pereira ${ }^{4}$, Newton Deniz Piovesan ${ }^{2}$ and Everaldo Gonçalves de Barros ${ }^{5}$

Received 07 March 2013

Accepted 20 January 2014

\begin{abstract}
Resistant lines can be identified by marker-assisted selection (MAS), based on alleles of genetic markers linked to the resistance trait. This reduces the number of phenotypically evaluated lines, one of the limitations in the development of cultivars with resistance to soybean cyst nematode (SCN). This study evaluated the efficiency of microsatellites near quantitative trait loci ( $Q T L)$ for $S C N$ resistance, in the linkage groups $(L G) G$ and $A 2$ of soybean, for the selection of resistant genotypes in populations originated from crosses between the cultivars Vmax and CD201. The QTL of LG A2 was not detected in 'Vmax'(derived from PI 88788). In MAS, the microsatellites of $L G G$ were efficient in selecting $F_{6: 7}$ families with resistance and moderate resistance to $S C N$ race 3 . The selection efficiency of the microsatellites Sat_168, Satt309 and Sat_141 was greater than 93\%.
\end{abstract}

Key words: $M A S$, Glycine max, SCN, microsatellites, QTL.

\section{INTRODUCTION}

The soybean cyst nematode (SCN), Heterodera glycines Ichinohe, is worldwide the main pathogen of soybean (Wrather et al. 2001). The most efficient and economical control method is the use of resistant cultivars, together with rotation with non-host crops (Embrapa 2010). However, the development of resistant cultivars is limited by factors such as phenotypic analysis of segregating populations, which is time consuming, labor-intensive and requires much space in the greenhouse (Young and Mudge 2002, Cervigni et al. 2004, Concibido et al. 2004).

The development of 1,000 microsatellites (Simple Sequence Repeat) led to the construction of an integrated and saturated consensus map for soybean (Cregan et al. 1999a, Song et al. 2004). Thus, the markers near important QTL (Quantitative Trait Loci) can be used as anchors for locating regions in the linkage map in different populations (Schuster et al. 2001).

Several QTL linked to the resistance to different SCN

races were identified and validated in different soybean genotypes (Concibido et al. 2004). One of the QTL with major effect in LG G, designated $r h g 1$, confers resistance to several races (Chang et al. 1997, Concibido et al. 1997, Meksem et al. 2001, Yue et al. 2001, Glover et al. 2004, Silva et al. 2007b), while another in LG A2 (Rhg4), with major effect, confers specific resistance to race 3 (Mahalingam and Skorupska 1995, Webb et al. 1995, Chang et al. 1997, Meksem et al. 2001, Wang et al. 2004).

Marker-assisted selection (MAS) is an important tool to overcome difficulties of phenotypic selection, in the identification of SCN-resistant lines in segregating populations (Young and Mudge 2002, Concibido et al. 2004) and represents a useful alternative in the development of resistant cultivars.

This study evaluated the effectiveness of using microsatellite near the loci $r h g 1$ and Rhg4, for the selection of soybean lines resistant to $\mathrm{SCN}$ race 3 .

\section{MATERIAL AND METHODS}

\footnotetext{
${ }^{1}$ Universidade Estadual do Norte Fluminense Darcy Ribeiro, Laboratório de Melhoramento Genético Vegetal, 28.013-602, Campos dos Goytacazes, RJ, Brazil. *E-mail: fsantana_ufv@yahoo.com.br

${ }^{2}$ Universidade Federal de Viçosa, Instituto de Biotecnologia Aplicada à Agropecuária, 36.570-900, Viçosa, MG, Brazil

${ }^{3}$ Universidade Federal do Espírito Santo, Alto Universitário, S/N, 29.500-000, Alegre, ES, Brazil

${ }^{4}$ Embrapa Soja, C. P. 231, 86.001-970, Londrina, PR, Brazil

${ }^{5}$ Universidade Católica de Brasília, 70.790-160, Brasília, DF, Brazil
} 


\section{Plant material}

From crosses between isolines derived from the cultivars Vmax (resistant to SCN races 3 and 14) and CD 201 (SCNsusceptible), $65 \mathrm{~F}_{5}$ soybean populations were obtained by the single pod descent (SPD) method). These populations were derived from the breeding program for soybean quality of the institute BIOAGRO at the Federal University of Viçosa (UFV) (Figure 1A).

\section{Marker-assisted breeding strategy}

The selected microsatellites were chosen for being in regions close to QTL for SCN resistance, i.e., in the region from 0.0 to $10.06 \mathrm{cM}$ of the $\mathrm{LG} \mathrm{G}$ on the consensus map, comprising the region of the SSR Satt163, Satt038, Satt275, Sat_168, Satt309, Sat_141, and Sat_163, as well as the region of LG A2, from 51.57 to $58.44 \mathrm{cM}$, with the SSR Sat_157, Sat_162, BLT 065, Satt187, GMENOD 2B (Song et al. 2004).

The polymorphic microsatellites between the parents "Vmax" and "CD201" were amplified in DNA seed bulks of each of the $65 \mathrm{~F}_{5}$ populations and seven $\mathrm{F}_{5}$ populations were selected on microsatellite alleles close to the resistance QTL. Of these seven, four populations were simultaneously selected on polymorphism of microsatellites of LG G and A2 and three on microsatellite polymorphism in LG A2 only. The selected populations were sown in bulks by the SPD method to obtain the $\mathrm{F}_{6}$ generation. At harvest, the plants were threshed separately and $64 \mathrm{~F}_{6: 7}$ families were obtained (Figure 1B). These families were phenotyped for race 3 (HG Type 5.7) of SCN.

\section{Phenotypic evaluation}

The experiment was carried out in a greenhouse (25-30 ${ }^{\circ} \mathrm{C}$ and 16 hours of light) of Embrapa Soja, in Londrina, Paraná. The experiment was arranged in a completely randomized design with seven replications.

Seeds from $64 \mathrm{~F}_{6: 7}$ families were sown separately in plastic pots with sand. The same procedure was applied to the seven soybean lines ('Peking', PI 88788, PI 90763, PI 437654, PI 209332, PI 89772, and PI548316), to classify the HG types of the SCN populations, as proposed by Niblack et al. (2002), and to the susceptibility control Lee 74. Three days after germination, the seedlings were transplanted to 1 $\mathrm{kg}$ clay pots, containing a soil-sand mixture (1:3). At transplanting, each plant was inoculated with 4,000 SCN eggs of race 3 as described by Dias et al. (1998). The soybean plants were grown in a greenhouse for 28 days. Thereafter, leaves of each plant were collected for DNA extraction and recovery of the nematode females.

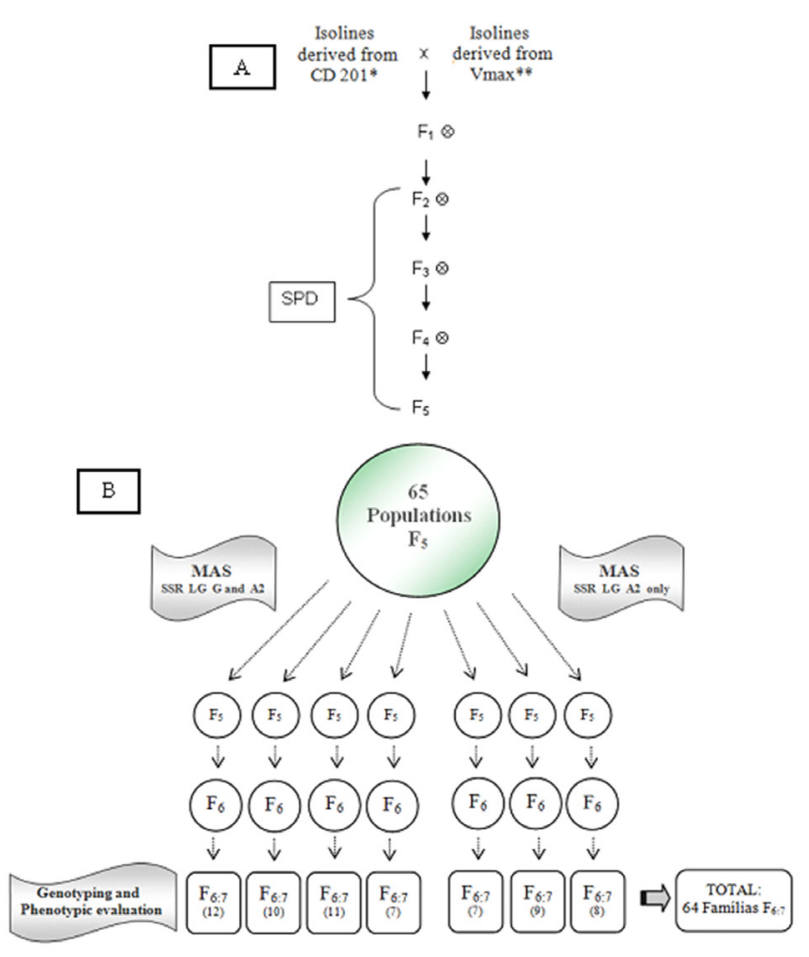

Figure 1. Scheme of crosses leading to the $65 \mathrm{~F}_{5}$ populations and sequentially to the $64 \mathrm{~F}_{6 \cdot 7}$ families A - Descent steps of the $65 \mathrm{~F}_{5}$ populations obtained by the single pod descent (SPD) method; B - Marker-assisted selection (MAS) and establishment of F6:7 families selected on polymorphism of microsatellites (SSR) of linkage groups (LG) G and A2. Figures in brackets represent the number of $F_{6 \cdot 7}$ families derived from selected $\mathrm{F}_{5}$ populations. * protein source derived from Barc-8; ** protein source derived from BR80-14883

For female extraction, each plant was carefully removed from the pot and the root system washed on sieves of 20 and 100 mesh under a strong water jet. After quantifying the females with a gridded acrylic plate and stereoscopic microscope, the female index (FI) was calculated for each $\mathrm{F}_{6: 7}$ family. The reaction of the $\mathrm{F}_{6: 7}$ families was classified by the criterion of Schmitt and Shannon (1992), i.e., families with $\mathrm{FI}<10 \%$ were considered resistant; $10 \% \leq \mathrm{FI} \leq 30 \%$ moderately resistant; and $\mathrm{FI} \geq 31 \%$ susceptible.

\section{Genotypic analysis}

For DNA extraction, leaves were collected from plants of different families prior to phenotypic analysis. The extraction followed the protocol of Doyle and Doyle (1990), modified by Abdelnoor et al. (1995). From each $\mathrm{F}_{6: 7}$ family, DNA bulks with seven plants were obtained for subsequent genotyping with the microsatellites Satt 309, Sat_141 and Sat_168 (Figure 1B).

Amplification reactions were performed in a final volume 
of $15 \mu \mathrm{L}$ containing $10 \mathrm{mM}$ Tris- $\mathrm{HCl}, \mathrm{pH} 8.3,50 \mathrm{mM} \mathrm{KCl}$, $2 \mathrm{mM} \mathrm{MgCl}{ }_{2}, 100 \mu \mathrm{M}$ of each deoxynucleotide, $0.3 \mu \mathrm{M}$ of each primer, one unit of Taq polymerase, and $30 \mathrm{ng}$ of DNA. The PCR program consisted of: $94{ }^{\circ} \mathrm{C}$ for $4 \mathrm{~min}$, 30 cycles of $94{ }^{\circ} \mathrm{C}$ for $1 \mathrm{~min}, 55^{\circ} \mathrm{C}$ for $1 \mathrm{~min}, 72^{\circ} \mathrm{C}$ for $2 \mathrm{~min}$, and subsequent $72^{\circ} \mathrm{C}$ for $7 \mathrm{~min}$. The amplification products were separated by electrophoresis in $10 \%$ native polyacrylamide gels using $1 \mathrm{X}$ TAE buffer $(1 \mathrm{mM}$ Trisacetate $40 \mathrm{mM}$, EDTA) at 140 volts, subsequently stained with ethidium bromide $\left(10 \mathrm{mg} \mathrm{mL}^{-1}\right)$ and photographed.

\section{Statistical analysis}

For analysis of variance and establishment of the genetic parameters, we used software Genes (Cruz 2013). The efficiency of selection (SE) of the microsatellite loci linked to $\mathrm{SCN}$ resistance was based on the comparison between the phenotypic and genotypic analyses and was calculated as described by Silva et al. (2007b):

$$
S E=100[M F M F+m f m f) /(M M+m m)]
$$

where:

$M F M F$ - number of families selected correctly as resistant, based on the marker and phenotypic analysis;

$m f m f$ - number of families selected correctly as susceptible, based on the marker and phenotypic analysis, and

$M M+m m-$ total of families selected as resistant and susceptible, based on markers only.

The SE was calculated using both the criterion of resistance, considering an index of parasitism (IP) of $<10$ as well as moderate resistance, with IP $<30$ (Schmitt and Shannon 1992).

\section{RESULTS AND DISCUSSION}

Three microsatellites of LG G (Satt309, Sat_168 and Sat_141) and one from LG A2 (Satt187) were polymorphic in the parents. These were used in the assisted selection performed in DNA seed bulks of each of the $65 \mathrm{~F}_{5}$ populations. Based on the resulting polymorphism, seven segregating $\mathrm{F}_{5}$ populations were selected by microsatellites, four of which of both LG and three of LG A2 only. The other populations were not polymorphic for the tested microsatellites.

\section{Phenotypic evaluation of the selected populations}

The $64 \mathrm{~F}_{6: 7}$ families derived from the seven selected $\mathrm{F}_{5}$ populations were phenotyped for resistance to $\mathrm{SCN}$ race 3 (HG type 5.7). The lowest and highest mean numbers of females were found in population 1; transgressive segregation was observed in this population only, for both reduction and increase of the number of females, compared to the means of the parents. In the other populations, transgressive segregation occurred only for increase in the number of females (Table 1). This type of segregation was also observed for resistance to $\mathrm{SCN}$ race 14, which was attributed to possible effects of gene interaction in the control of resistance (Silva et al. 2007a).

All populations except 3 and 4 had a higher mean number of females than the susceptible parent (Table 1). The different resistance level of the families in each population indicated that the parents (isolines) derived from Vmax may have failed to recover all resistance genes, particularly minor-effect genes. Another possibility is that the population size did not allow the detection of a combination with all alleles. In this case, it would be necessary to study strategies that would allow the evaluation of a greater number of genotypes.

By the classification based on the index of parasitism of $\mathrm{F}_{6: 7}$ families of each population (Table 2) and resistant or moderately resistant and susceptible families were identified in the four $\mathrm{F}_{5}$ populations, selected on SSR polymorphism of LG $\mathrm{G}$ and A2. However, the $\mathrm{F}_{6: 7}$ families derived from the three selected $\mathrm{F}_{5}$ populations with LG A2 only were susceptible.

The results of the analysis of variance and estimates of genetic parameters of each $\mathrm{F}_{5}$ population are shown in Table 3. Significant genetic variance of $1 \%$ was found among $\mathrm{F}_{6: 7}$ families, originating from the $\mathrm{F}_{5}$ populations selected on the basis of SSR of LG G and A2 (Table 3). This allowed the

Table 1. Mean, minimum and maximum numbers of females detected by the phenotypic analysis of $F_{6: 7}$ families of the selected $F_{5}$ populations

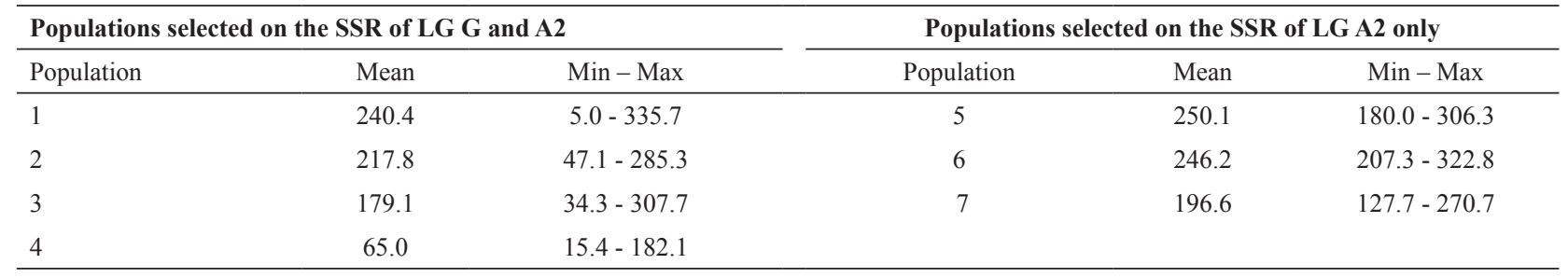

Mean of the resistant parent: 7.7; Mean of the susceptible parent: 191.0. 
selection for the best families in these populations. In the $\mathrm{F}_{6: 7}$ families of the populations selected by the microsatellite of LG A2 (Satt187), no genetic variability for resistance to race 3 was found (Table 3), indicating the absence of segregation of the resistance gene Rhg4 of LG A2 in these populations. Thus, LG A2 markers should not be used in marker-assisted selection in Vmax-derived populations (descendant from PI 88788). For this reason, the discussion below focuses only on populations with significant genetic variability.

The heritability estimates ranged from 75.9 to $95.7 \%$. The high heritability detected may be a result of the high level of homozygosis of the studied families, the small number of major genes involved and of the environmental control in the experiment. According to Falconer and Mackay (1996), heritability estimates depend on the plant material, the estimation method and the experiment.

Webb et al. (1995) reported a broad-sense heritability of $97 \%$ for resistance to race 3 in crosses with PI 437654.
Therefore, the efficiency of phenotypic selection is high for this $\mathrm{SCN}$ race.

\section{Genotypic evaluation of selected $F_{6: 7}$ families}

The second genotypic evaluation assessed DNA bulks of seven plants from each $\mathrm{F}_{6: 7} \mathrm{~F}_{5}$ families derived from the selected populations. These families were genotyped using only the LG G microsatellites, since the $\mathrm{F}_{6: 7}$ families of the populations selected by marker Satt 187 of LG A2 were highly susceptible, indicating that this marker was not linked to $\mathrm{SCN}$ resistance in the studied populations.

Although the Satt187 marker of LG A2 is close to the resistance locus $R h g 4$, there is no evidence that this resistance allele is present in the resistant parent Vmax, which was derived from the resistance source PI 88788. Glover et al. (2004) studied PI 88788 and identified QTL in LG G and J by composite interval mapping at the $5 \%$ level of significance, but mentioned no QTL for SCN resistance in the region of LG A2. Concibido et al. (1997) found no resistance locus

Table 2. Number of resistant, moderately resistant, moderately susceptible and susceptible $\mathrm{F}_{6: 7}$ families, according to the criterion of the index of parasitism (IP)

\begin{tabular}{|c|c|c|c|c|c|c|c|c|c|}
\hline \multirow{2}{*}{ Phenotype of $F_{6: 7}$ families } & \multicolumn{5}{|c|}{$F_{5}$ populations selected on the SSRs of LG G and A2 } & \multicolumn{4}{|c|}{$F_{5}$ populations selected on the SSR of LG A2 only } \\
\hline & 1 & 2 & 3 & 4 & Total & 5 & 6 & 7 & Total \\
\hline $\mathrm{R}$ & 1 & - & - & 3 & 4 & - & - & - & - \\
\hline $\mathrm{S}$ & 11 & 9 & 10 & 2 & 32 & 7 & 9 & 8 & 24 \\
\hline Total $\mathrm{F}_{6: 7}$ families* & 12 & 10 & 11 & 7 & 40 & 7 & 9 & 8 & 24 \\
\hline
\end{tabular}

* Number of plants evaluated in each $\mathrm{F}_{6: 7}$ family, varying from 5 to 7 ; R - resistant $(\mathrm{IP}<10) \mathrm{MR}$ - moderately resistant $(10 \leq \mathrm{IP}<30) \mathrm{S}$ - susceptible-S (IP $\geq 60$ ).

Table 3. Estimates of genetic parameters obtained from a phenotypic evaluation for race 3 (HG Type 5.7) in $\mathrm{F}_{6: 7}$ families, derived from seven selected $\mathrm{F}_{5}$ populations, based on microsatellite markers of LG G and A2

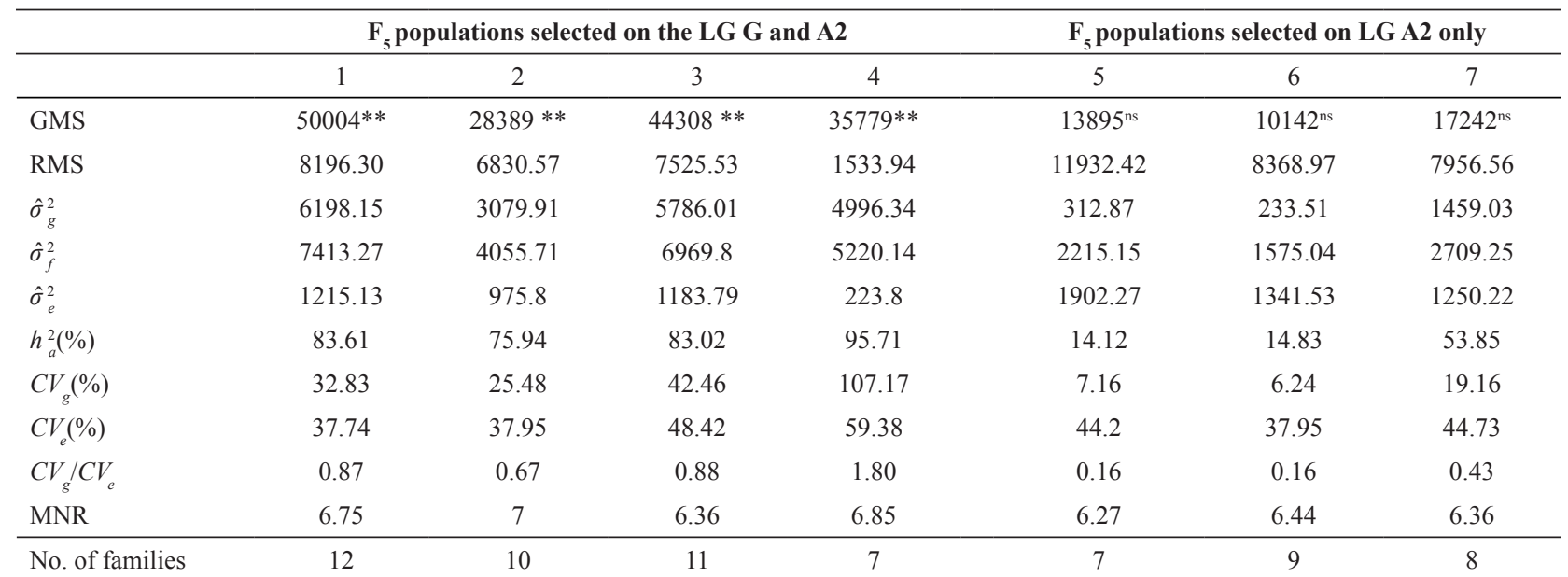

** significant at 1\% probability ns: non-significant GMS and RMS: Genotype mean squares and and residual mean squares, respectively; $\hat{\sigma}_{g}^{2}$ : estimate of genetic variance; $\hat{\sigma}_{f}^{2}$ : estimate of phenotypic variance; $\hat{\sigma}_{e}^{2}$ : estimate of environmental variance; $h_{a}^{2}(\%)$ : broad-sense heritability, in percentage; $C V:$ coefficient of genetic variation, in percentage; $C V_{e}$ : coefficient of experimental variation, in percentage; MNR: mean number of replications (plants); $\mathrm{CV}_{\mathrm{g}} / \mathrm{CV}_{\mathrm{e}}:$ variation index. 
for race 3 in LG A2 either in the same resistance source. Therefore, the locus for SCN race-3 resistance in LG A2 is probably absent in PI 88788.

However, LG A2 is important to control resistance to $\mathrm{SCN}$ race 3 in different resistance sources, such as PI 209332 (Concibido et al. 1994), Peking (Mahalingam and Skorupska 1995, Chang et al. 1997, Meksem et al. 2001), PI 437654 (Webb et al. 1995, Prabhu et al. 1999), PI 90763 (Guo et al. 2005) and Hartwig (Silva et al. 2007b).

\section{Genotype - phenotype analysis of $F_{6: 7}$ families}

The four phenotypically resistant $F_{6: 7}$ families carried resistance alleles of the three microsatellite markers LG G (Satt309, Sat_168 and Sat_141), indicating that these markers are extremely efficient in the selection of resistant families.

Of the four moderately resistant $\mathrm{F}_{6: 7}$ families, three carried resistance alleles of the LG G microsatellites, indicating that these markers did not distinguish resistant from moderately resistant families. Within these families, plants with resistance, moderate resistance and moderate susceptibility were observed. This demonstrates that in addition to the resistance QTL of LG G, other resistance (minor effect) QTL are needed for complete resistance to SCN race 3 in Vmax-derived populations. The QTL of LG $\mathrm{G}$ is known to explain much of the resistance to $\mathrm{SCN}$ race 3 in different resistance sources. Complete resistance however requires minor-effect genes that are not always identified (Concibido et al. 2004).

It was found that five $\mathrm{F}_{6: 7}$ families derived from the four genotyped populations were classified as susceptible in spite of carrying resistance alleles of the evaluated microsatellites, indicating the existence of segregating resistance genes in these families, since plants with moderate resistance were found in the families.

\section{Selection efficiency}

The selection efficiency was evaluated considering all
$\mathrm{F}_{6.7}$ families of the four populations together. With the SSR Sat_168, a selection efficiency of $97.05 \%$ was reached and 96.55 and $93.55 \%$, with Satt309 and Sat_141, respectively. The pairwise combinations of the microsatellites raised the SE to $100 \%$, in all cases (Table 4).

The selection efficiency increased little when the criterion of moderate resistance (IP < 30) was used for calculations (Table 4). In all cases, the discrimination of resistant families did not raise the efficiency, unlike the correct classification of the susceptible ones.

These data confirmed that these markers are very close to locus rhgl, which has been extensively studied for explaining a large phenotypic variation of the $\mathrm{SCN}$ resistance to race 3 and other races (Concibido et al. 2004), and proved their usefulness in the selection of the assessed populations and that they can be used in other Vmax-derived populations.

Cregan et al. (1999b) reported that the SSR Satt309 and Sat 168 are at a distance of $0.4 \mathrm{cM}$ from locus $r h g 1$ and the use of one of these markers would ensure success in genotypic selection. High selection efficiency was also reported by Mudge et al. (1997) in the identification of race3 resistant lines with SSR flanking only the region of gene $r h g 1$, with an accuracy of $98 \%$. Silva et al. (2007b) also reported high selection efficiency (94\%) for race-3 resistance in $F_{2: 3}$ families with only one SSR of LG G: Satt309.

However, the high SE values reported in the literature were obtained in mapping populations, where the QTL was detected in the study population. This particular study deals with a breeding population in advanced generations; nevertheless, it was possible to obtain high selection efficiency with the SSR of LG G, near locus rhg1.

\section{ACKNOWLEDGEMENTS}

The authors wish to thank the National Council for Scientific and Technological Development (CNPq) and the Brazilian Federal Agency for Support and Evaluation of Graduate Education (CAPES) for funding this study.

Table 4. Selection efficiency (SE) of microsatellite markers for resistance to SCN race 3 in the evaluated populations, using the index of parasitism (IP) as criterion of resistance (IP $<10$ ) and moderate resistance (IP $<30$ )

\begin{tabular}{lcc}
\hline Marker & SE\% (IP $<$ 10) & SE\% (IP $<$ 30) \\
\hline Sat_168 & 97.05 & 97.29 \\
Satt309 & 96.55 & 96.87 \\
Sat_141 & 93.55 & 94.12 \\
Sat_168 + Sat_141 & 100 & 100 \\
Satt309 + Sat_141 & 100 & 100 \\
Sat_168 + Satt309 & 100 & 100 \\
\hline
\end{tabular}




\title{
Estratégias de seleção assistida por marcadores para desenvolvimento de plantas de soja resistentes ao nematoide de cisto
}

\begin{abstract}
Resumo - A seleção assistida por marcadores (SAM) permite identificar linhagens resistentes com base em alelos de marcadores genéticos ligados ao caráter, o que reduz o número de linhagens avaliados fenotipicamente, uma das limitações ao desenvolvimento de cultivares resistentes ao nematoide de cisto da soja (NCS). Neste trabalho objetivou-se avaliar a eficiência de microssatélites próximos a QTLs de resistência ao NCS, nos grupos de ligação (GL) Ge A2 da soja, na seleção de genótipos resistentes em populações originadas do cruzamento entre as cultivares Vmax e CD201. O QTL do GL A2 não foi detectado em 'Vmax'(derivada da PI 88788). A SAM por microssatélites do GL G foi eficiente na seleção de familias $F_{6: 7}$ resistentes e moderadamente resistentes à raça 3 do NCS. Os microssatélites Sat_168, Satt309 e Sat_141 apresentaram eficiência de seleção maior que 93\%.
\end{abstract}

Palavras-chave: SAM, Glycine max, NCS, microssatélites, QTLs.

\section{REFERENCES}

Abdelnoor RV, Barros EG and Moreira MA (1995) Determination of genetic diversity within Brazilian soybean germplasm using random amplified polymorphic DNA techniques and comparative analysis with pedigree. Revista Brasileira de Genética 18: 265-273.

Cervigni GDL, Schuster I, Barros EG and Moreira MA (2004) Two microsatellite markers flanking a dominant gene for resistance to soybean cyst nematode race 3. Euphytica 135: 99-105.

Chang SJC, Doubler TW, Kilo VY, Abu-Thredeih J, Prabhu R, Freire V, Suttner R, Klein J, Schmidt ME, Gibson PT and Lightfoot DA (1997) Association of loci underlying field resistance to soybeans sudden death syndrome (SDS) and cyst nematode $(\mathrm{SCN})$ race 3. Crop Science 37: 965-971.

Concibido VC, Denny RL, Boutin SR, Hautea R, Orf JH and Young ND (1994) DNA marker analysis of loci underlying resistance to soybean cyst nematode (Heterodera glycines Ichinohe). Crop Science 34: 240-246.

Concibido VC, Douglas L, Denny RL, Orf JH and Young ND (1997) Genome mapping of soybean cyst nematode resistance genes in Peking, PI 90763, and PI 88788 using DNA markers. Crop Science 37: 258-264.

Concibido VC, Diers BW and Arelli PR (2004) A decade of QTL mapping for cyst nematode resistance in soybean. Crop Science 44: 1121-1131.

Cregan PB, Jarvik T, Bush AL, Shoemaker RC, Lark KG, Kahler AL, Kaya N, Vantoai TT, Lohnes DG, Chung J and Specht JE (1999a) An integrated genetic linkage map of the soybean. Crop Science 39: $1464-1490$

Cregan P, Mudge J, Fichus EW, Denny DR and Young ND (1999b) Two simple sequence repeat markers to select for soybean cyst nematode resistance conditioned by the rhg1 locus. Theoretical Applied Genetics 99: 811-818.

Cruz CD (2013) GENES - a software package for analysis in experimental statistics and quantitative genetics Acta Scientiarum Agronomy 35: 271-276.

Dias WP, Silva JFV, Kiihl RAS, Hiromoto DM and Abdelnoor RV (1998) Quebra da resistência da cv. Hartwig por população de campo do nematóide de cisto da soja (Heterodera glycines). Pesquisa
Agropecuária Brasileira 33: 971-973.

Doyle JJ and Doyle JL (1990) Isolation of plant DNA from fresh tissue. Focus 12: 13-15.

Embrapa - Empresa Brasileira de Pesquisa Agropecuária (2010) Tecnologias de produção de soja região Central do Brasil 2011. Embrapa, Londrina, 255p.

Falconer DS and Mackay TFC (1996) Introduction to quantitative genetics. $4^{\mathrm{a}}$ ed., Longman, Edinburgh, $464 \mathrm{p}$.

Glover KD, Wang D, Arelli PR, Carlson SR, Cianzio SR and Diers BW (2004) Near isogenic lines confirm a soybean cyst nematode resistance gene from PI 88788 on linkage group J. Crop Science 44: 936-941.

Guo B, Sleper DA, Arelli PR, Shannon JG and Nguyen HT (2005) Identification of QTL associated with resistance to soybean cyst nematode races 2, 3 and 5 in soybean PI 90763. Theoretical Applied Genetics 111: 965-971.

Mahalingam R and Skorupska HT (1995) DNA markers for resistance to Heterodera glycines race 3 in soybean cultivar Peking. Breeding Science 45: 435-443.

Meksem K, Pantazopoulos P, Njiti VN, Hyten LD, Arelli PR and Lightfoot DA (2001) 'Forrest' resistance to the soybean cyst nematode is bigenic: saturation mapping of the $R h g 1$ and $R h g 4$ loci. Theoretical Applied Genetics 103: 710-717.

Mudge J, Cregan PB, Kenworthy JP, Kenworthy JW, Orf JH and Young ND (1997) Two microsatellite markers that flank the major soybean cyst nematode resistance locus. Crop Science 37: 1611-1615.

Niblack TL, Arelli PR, Noel GR, Opperman CH, Orf JH, Schmitt DP, Shannon JG and Tylka GL (2002) A revised classification scheme for genetically diverse populations of Heterodera glycines. Journal of Nematology 34: 279-288.

Prabhu RR, Njiti VN, Bell Johnson B, Johnson JE, Schmidt ME, Klein JH and Lightfoot DA (1999) Selecting soybean cultivars for dual resistance to soybean cyst nematode and sudden death syndrome using two DNA markers. Crop Science 39: 982-987.

Schmitt DP and Shannon G (1992) Differentiating soybean to Heterodera glycines races. Crop Science 32: 275-277.

Schuster I, Abdelnoor RV, Marin SRR, Carvalho VP, Kiihl RAS, Silva JFV, 
FA Santana et al.

Sediyama CS, Barros EG and Moreira MA (2001) Identification of a new major QTL associated with resistance to soybean cyst nematode (Heterodera glycines). Theoretical Applied Genetics 102: 91-96.

Silva MF, Schuster I, Cervigni GDL, Silva JFV, Dias WP, Ferreira A, Barros EG and Moreira MA (2007a) Inheritance of resistance to soybean cyst nematode races 3 and 14 in soybean RIL and F2 populations. Pesquisa Agropecuária Brasileira 42: 1735-1740.

Silva MF, Schuster I, Silva JFV, Ferreira A, Barros EG and Moreira MA (2007b) Validation of microsatellite markers for assisted selection of soybean resistance to cyst nematode races 3 and 14. Pesquisa Agropecuária Brasileira 42: 1143-1150.

Song QJ, Marek LF, Shoemaker RC, Lark KG, Concibido VC, Delannay X, Spetch JE and Cregan PB (2004) A new integrated genetic linkage map of the soybean. Theoretical Applied Genetics 109: 122-128.

Wang D, Graef GL, Procopiuk AM and Diers BW (2004) Identification of putative QTL that underlies yield in interspecific soybean backcross populations. Theoretical Applied Genetics 108: 458-467.

Webb DM, Baltazar BM, Rao-Arelli AP, Schupp J, Clayton K, Keim P and Beavis WD (1995) Genetic mapping of soybean cyst nematode race-3 resistance loci in the soybean PI 437654. Theoretical Applied Genetics 91: 574-581.

Wrather J, Anderson T, Arsyad D, Tan Y, Ploper L, Porto-Puglia A, Ram $\mathrm{H}$ and Yorinori J (2001) Soybean disease loss estimates for the top ten soybean producing countries in 1998. Canadian Journal Patholology 23: 115-121.

Young ND and Mudge J (2002) Marker-Assisted Selection for Soybean Cyst Nematode Resistance. In Starr JL, Cook R and Bridge J (Eds) Plant resistance to parasitic nematodes. CABI Publishing, New York, p. 241-251.

Yue P, Sleper DA and Arelli PR (2001) Mapping resistance to multiple races of Heterodera glycines in soybean PI 89772. Crop Science 41: 1587-1595. 